\title{
THE CYPRIOT EXEMPTION FROM EVOCATIO AND THE CHARACTER OF CICERO'S PROCONSULSHIP
}

Q. Volusium, tui Tiberi generum, certum hominem et mirifice abstinentem, misi in Cyprum ut ibi pauculos dies esset, ne cives Romani pauci qui illic negotiantur ius sibi dictum negarent; nam evocari ex insula Cyprios non licet.

(Cic. Att. 5.21.6)

I sent Quintus Volusius, the son-in-law of your friend Tiberius, a man both trustworthy and extraordinarily moderate, to Cyprus for only a couple of days, lest the few Roman citizens who do business there should claim that they had no legal recourse available to them, since it is not permitted for Cypriots to be summoned off the island. ${ }^{1}$

Scholars have taken slight notice (if they mention it at all) of Cicero's interesting comment that Cypriots were exempt from evocatio, the summons of a defendant or witness to a legal proceeding by a Roman magistrate with imperium. ${ }^{2}$ While the legal ramifications of the ban on evocatio on Cyprus are clear, the origin of this exemption is not. The only explicit theory on its origin - Badian's argument that the prohibition was part of Lentulus' lex provinciae, a law for the formal organization of the province of Cyprus - has been influential, though it is based on tenuous evidence. ${ }^{3}$ Few ancient sources for Roman rule

\footnotetext{
* Earlier versions of this article were read at the 2007 meeting of the American Philological Association and the 2009 meeting of the Classical Association of the Middle West and South. I am grateful for the valuable comments, suggestions, and corrections made by the anonymous reviewer at Greece $\mathcal{E}$ Rome; any remaining errors are mine alone.

${ }^{1}$ All translations are mine unless otherwise indicated. Citations from Cicero's letters are taken from D. R. Shackleton Bailey, Cicero's Letters to Atticus. Volume III, 51-50 B.C. (Cambridge, 1968) and idem, Cicero Epistulae Ad Familiares. Volume I, 62-47 B.C. (Cambridge, 1977). All dates are BCE.

${ }^{2}$ R. Y. Tyrrell and L. C. Purser (eds.), The Correspondence of M. Tullius Cicero. Volume III (Hildesheim, 1914), 181; T. Petersson, Cicero. A Biography (Berkeley, CA, 1920); K. Büchner, 'M. Tullius Cicero', RE 2.7.1 (1939); Shackleton Bailey (n. 1), 1968, 235; M. Gelzer, Cicero. Ein biographische Versuch (Wiesbaden, 1969), 228-31; D. Stockton, Cicero. A Political Biography (Oxford, 1971); G. Hill, A History of Cyprus. Vol. I, second edition (Cambridge, 1972), 227; W. K. Lacey, Cicero and the End of the Roman Republic (New York, 1978), 99; H. Cotton, 'Cicero, Ad Familiares XIII, 26 and 28: Evidence for revocatio or reiectio Romae/Romam?', $7 R S 69$ (1979), 48, n. 67; T. B. Mitford, 'Roman Cyprus', $A N R W$ ii.7.2 (1980), 1294; E. Rawson, Cicero. A Portrait (Ithaca, NY, 1983), 171. Only legal evocatio, not religious (Livy 5.21; cf. Macrob. Sat. 3.9.6; Plin. HN 30.6) or military evocatio (Rhet. Her. 3.3; B Alex. 56.6) is considered here.

${ }^{3}$ E. Badian, 'M. Porcius Cato and the Annexation and Early Administration of Cyprus', FRS 55 (1965), 115; cf. A. N. Sherwin-White, Roman Foreign Policy in the East. 168 B.C. to A.D. 1 (Norman, OK, 1984), 268; and R. Bernhardt, Polis und römische Herrschaft in der späten Republik (149凶31 v.Chr.) (Berlin, 1985), 108. A. J. Marshall, 'Governors on the Move', Phoenix 20
} 
on Cyprus during the Late Republic have survived, and we must rely almost entirely on Cicero's letters. Cicero's correspondence, however, indicates (against Badian) that the ban on evocatio was a codicil of Cicero's provincial edict, and not a part of either Lentulus' lex provinciae or his provincial edict. Personal, political, and military considerations all played a role in Cicero's decision to make the citizens of Cyprus exempt from being called to the administrative gathering for the dispensation of justice and other legal and political matters known as a conventus. ${ }^{4}$

We should begin with what we can deduce with relative certainty about the legal situation on Cyprus during Cicero's proconsulship. First, as a proconsul with imperium, Cicero had the power to summon Roman citizens who lived or worked on the island to the mainland. Second, the phrase ex insula, 'from the island', indicates that Cicero was able to summon Cypriots to a meeting on the island. The Salaminian delegations that met Cicero at Ephesus and Tarsus went voluntarily, not out of fear that they would not have a chance to make their case at a hearing on Cyprus but because approaching a governor was common practice for provincials seeking redress of grievances (compare Cic. Att. 5.13.1; Cic. Fam. 3.8.4). Third, Volusius' trip must have been arranged far in advance, for there would be no reason to send a legate to the island if the Roman citizens there did not know where to find him. We may thus infer the existence of a conventus on the island at this early date, though we have no explicit reference to a Cypriot conventus until the imperial period (Ptol. Geog. 5.13.5).

We can also assume that the prohibition on evocatio was in place by the time that Att. 5.21.6 was written in February 50, and far enough in advance of Cicero's arrival for this provision to be made known to the Roman citizens on Cyprus. Cicero left Rome for Cilicia sometime in May 51, having composed his provincial edict before his departure (Fam. 3.8.4). He also comments in this letter that he had added nothing to his provincial edict after its composition except a single paragraph regarding the tax-farmers (nihil addidi nisi quod publicani me rogarunt cum Samum ad me venissent). Further, because Volusius was sent for only a few days the implication is that there must not have been much business to attend to on Cyprus, and that the cases

(1966), 231, n. 2, mentions Cic. Att. 5.21.6 as evidence for the legal position of Roman citizens on Cyprus but provides no discussion.

${ }^{4}$ On the conventus, otherwise known as an assize, see E. Kornemann, 'Conventus', $R E 4$ (1900), 1182-1200. 
he heard were civil rather than criminal. ${ }^{5}$ As Cicero specifies that Volusius is heading to Cyprus only for the benefit of the small number of Roman citizens who are transacting business there, Volusius' brief stay further indicates that he was not concerned in resolving disputes involving only Cypriots - he would simply not have had the time. ${ }^{6}$

Furthermore, the phrase non licet, 'it is not permitted', in Att. 5.21.6 indicates that the Cypriot exemption was the result of a legal measure; either a lex provinciae or a governor's edict would be sufficient for the institution of such a decree. ${ }^{7}$ The unusual nature of Cyprus' annexation, however, suggests that we should not look for nor even expect to find a lex provinciae for the island. The manner in which Cyprus became Roman territory in $58-57$ is well documented. ${ }^{8}$ P. Clodius, whether for personal reasons (Strabo 14.6.6; Dio Cass. 38.30.5; App. B Civ. 2.23) or monetary ones (Amm. Marc. 14.8.1415), forced through a plebiscite that authorized the deposition of King Ptolemy of Cyprus and the arrogation of his fortune for Rome's treasury. After Ptolemy's suicide, Cyprus was attached to Cilicia and came under the jurisdiction of the governor of that province.

Leaving aside the question of the legality of Clodius' legislation, there is no reason why Cyprus should have received an organizational law once it became subject to Rome. Despite the testimony of Livy (Ep. 104), Dio Cassius (38.30.5), Velleius Paterculus (2.38.6), and others (Pomp. Trog. Prol. 40), Cyprus did not receive a lex provinciae from Cato, or indeed from anyone else. Badian has proven conclusively that Cato lacked the legal authority to organize Cyprus as a province - he was empowered by Clodius only to annex the island and oversee the

${ }^{5}$ E. Oberhummer, 'Kypros', RE 12.1 (1925), 105. On the jurisdiction of governors and their judicial activity, see Marshall (n. 3); J. Richardson, 'The Administration of the Empire', in J. A. Crook, A. Lintott, and E. Rawson (eds.), The Cambridge Ancient History. Volume 9 (Cambridge, 1994), 589-91; and R. Kallet-Marx, Hegemony to Empire. The Development of the Roman Imperium in the East from 148 to 62 B.C. (Berkeley, CA, 1995), 126-60.

${ }^{6}$ A. Lintott, Cicero as Evidence (Oxford, 2008), 263, n. 39; cf. Kallet-Marx (n. 5), 134.

${ }^{7}$ On the provincial edict, see the still-valuable discussion by A. H. J. Greenidge, The Legal Procedure of Cicero's Time (Oxford, 1901), 119-25. A provincial edict lapsed at the expiration of its issuer's term of office, though the succeeding governor could continue a predecessor's mandates by reissuing them in his own decree; see T. Mommsen, Römisches Staatsrecht. Erster Band (Basel and Stuttgart, 1887), 207.

${ }^{8}$ The sources have been collected in T. R. S. Broughton, The Magistrates of the Roman Republic. Volume I (New York, 1951), 198. On Ptolemy XI Alexander II's will, which some claimed left Cyprus to the Romans in 80 (Cic. Leg. agr. 2.41), see G. De Sanctis, 'Il primo testamento regio a favore dei Romani', RFIC 10 (1932), 159-67; and I. Shatzman, 'The Egyptian Question in Roman Politics (59-54 в.C.)', Latomus 30 (1971), 363-4. 
deposition of the king, not to organize a new province. ${ }^{9}$ But Badian, following Rotondi, assigns Cyprus' lex provinciae to P. Cornelius Lentulus Spinther, governor of Cilicia from 56 to 53 . He bases his argument solely on the authority of a single letter from Cicero to C. Sextilius Rufus in 47 (Fam. 13.48). In that letter, Cicero advises Sextilius, who has been appointed quaestor for Cyprus, to be mindful of the legal measures of two previous governors of the province, Lentulus and Cicero himself (P. Lentuli necessari tui legem et ea quae a me constituta sunt, "the law of your relative Publius Lentulus and the measures that I have instituted'). Nowhere else, however, does Cicero mention a lex Lentuli ('law of Lentulus'), and, as Marshall argues, we lack any direct references to the details or components of this law. ${ }^{10}$

It was not necessary for a newly acquired area to receive a lex provinciae, and there are good reasons to doubt the very existence of such laws as they have usually been understood. ${ }^{11}$ Cyprus should rather be considered a provincia in the traditional sense of 'sphere of command' (Gk. eparchia; compare Strabo 14.6.6). As such Cyprus did not require a lex provinciae. It cannot be doubted that the governor of Cilicia had judicial and military authority over Cyprus, for Cicero addresses Lentulus as qui Ciliciam Cyprumque teneas, 'you who command both Cilicia and Cyprus' (Fam. 1.7.4). Cicero's attempts at mediation between the Salaminians and Brutus' agents (Att. 5.21.10$14,6.1 .2-8,6.2 .7-9,6.3 .5)$ further confirm his jurisdiction over the island, as does his claim that he had the power of coercion over the Salaminians (Att. 6.2.7).

If Cyprus did not receive a formal measure of provincial organization, we must then look for the origin of the ban on evocatio in the provincial edict of one of the first three governors of the united province of Cilicia-Cyprus. Cicero's edict is the most probable source. It is less likely that either Lentulus or Appius Claudius Pulcher, proconsul of Cilicia in 53-51, had instituted this provision and that Cicero had

\footnotetext{
${ }^{9}$ G. Rotondi, Leges publicae populi Romani. Elenco cronologico con una introduzione sull'attavità legislativa dei comizi romani (Hildesheim, 1962), 493. On Cato as the creator of the province of Cyprus and the author of Cyprus' lex provinciae, see S. I. Oost, 'Cato Uticensis and the Annexation of Cyprus', CPh 50 (1955); and Gelzer (n. 2), 178.

${ }^{10}$ A. J. Marshall, 'Cicero's Letter to Cyprus', Phoenix 18 (1964), 209. Broughton (n. 8), 210, and Badian (n. 3), 115, assign the ban on evocatio to it without discussion. Neither Shackleton Bailey (n. 1), 1977, nor Hill (n. 2), nor Mitford (n. 2) make any comment on the nature of this Lentulan law.

${ }^{11}$ See now P. Freeman, 'On the Annexation of Provinces to the Roman Empire', Classics Ireland 5 (1998), 38-46, who expands on the argument of B. D. Hoyos, 'Lex Provinciae and Governor's Edict', Antichthon 7 (1973), 47-53.
} 
borrowed it from their edicts. Cicero considered Appius - the brother of his tormentor Clodius and an opponent of his recall from exile (Att. 4.1.6) - a terrible governor (Att. 5.15.2, 5.16.4, 5.17.5, 5.21.10, 6.1.2). ${ }^{12}$ Appius had left Cilicia a perdita et plane eversa in perpetuum provincia, 'a pitiful and utterly broken province'. His depredations had more in common with a wild animal than a man (Att. 5.16.2; compare Att. 6.1.2), and he was prosecuted for extortion, albeit unsuccessfully, after his return to Rome (Fam. 3.10, 3.11.2, 8.6.1-3; Att. 6.2.10). Cicero found it necessary to rescind some of Appius' decrees (Att. 6.1.2), and Appius' refusal to leave Cilicia in a timely manner irked Cicero greatly. Given the character of his proconsulship, it seems quite unlikely that Appius would have concerned himself with the Cypriots' wellbeing, let alone act magnanimously towards Cyprus or any other part of his province.

Lentulus, on the other hand, had maintained a long friendship with Cicero. As aedile in 63 he had worked with Cicero to quell the Catilinarian conspiracy, and as consul in 57 he had urged Cicero's recall (Cic. Red. Sen. 5, 8-9, 26-7; Red. Pop. 11, 15, 17-18). Cicero's correspondence indicates collegiality and respect, if not outright friendship (Att. 3.22.2; Q fr. 1.4.5; Fam. 1.1.1, 1.7.1, 1.7.9). We should thus expect Cicero to have esteemed Lentulus' provincial edict more than Appius', regardless of the actual content of Lentulus' pronouncement. The mention of the lex Lentuli in Fam. 13.48 in combination with Cicero's own administrative mandates as the measures that Sextilius should follow is not surprising. The terminology used by Cicero in Fam. 13.48 seems to indicate a clear distinction between Lentulus' law and Cicero's provincial edict. Given, however, the likelihood that Cyprus never received a lex provinciae, Cicero must be referring to Lentulus' provincial edict or a supplementary law of unknown content. Furthermore, Cicero tends to mention the existing legal sources from which he borrowed for his own edict, such as $\mathrm{Q}$. Mucius Scaevola's highly regarded edict for Asia Minor (Cic. Att. 5.17.5, 6.1.15; compare Diod. Sic. 37.5.1-4; Livy, Per. 70; Val. Max. 8.15.6). Other than this single mention of the lex Lentuli, however, we have no further evidence for Lentulus' edict, though I find Marshall's suggestion - that this lex Lentuli was a supplemental law passed during

\footnotetext{
${ }^{12}$ For discussion of their icy relationship, see J. Hall, Politeness and Politics in Cicero's Letters (Oxford, 2009), 139-53.
} 
Lentulus' long proconsulship in Cilicia - to be persuasive. ${ }^{13}$ Cicero does mention that he had borrowed for his edict the provision that cases between provincial citizens should be tried under the laws of the litigants' own cities, especially if they were from the same city (Att. 6.2.4). It would be easy to assign the ban on evocatio to this mandate, since it is clear from Att. 5.21.6 that if Cypriots could not be summoned to the mainland then they must have had recourse to jurisdiction on their own island. Yet Volusius' specific constituents are the Roman citizens on Cyprus, not the Cypriots. This provision is thus of no concern for Volusius' mission, and cannot be the source of the exemption from evocatio.

If the prohibition on evocatio did not come from a lex provinciae for Cyprus or the edict of either of Cicero's predecessors, then it must have come from Cicero's own edict. While we lack any direct statement about the origin of the ban, the most explicit evidence for it as part of Cicero's edict comes from a series of letters to Atticus in which Cicero details his activities as governor and the nature and content of his provincial edict (Att. 5.16-6.3). From these letters we learn that Cicero has outstripped everyone in honour, justice, cordiality, and clemency (Att. 5.21.5; compare 6.2.5, 6.3.3). ${ }^{14} \mathrm{He}$ states that the provincials are more loyal to him than to any previous governor $(A t t .5 .18 .2)$, and that they were pleasantly surprised by his parsimony (Att. 5.16.3, 5.17.2, 5.21.7; Fam . 3.8.2), his dispensation of justice and legal freedoms (Att. 5.20.1, 6.1.15, 6.2.4), and his public modesty (Att. 5.21.7). Cicero takes special care to tell Atticus that he had given greater autonomy to the cities under his command and that everyone was satisfied by his arrangements (Att. 6.1.15). Although we should allow for some selfcongratulation in Cicero's letters - which he himself admits is part of his description of his activities (Att. 5.21.7) - we are nevertheless left with the impression that both Lentulus and Appius were accustomed to abusing their position for personal gain, particularly after the campaigning season was over (Att. 5.21.7, illud autem tempus quotannis ante me fuerat in hoc quaestu, 'furthermore, before my tenure, that time every year was used for this occupation'). We further learn that the cities of the province had not been paying their taxes for at least five

${ }^{13}$ Marshall (n. 10), 211-12; cf. D. Magie, Roman Rule in Asia Minor (Princeton, 1950), 173-5, and Büchner (n. 2), 983.

${ }^{14}$ V. Chapot, 'Les Romains et Cypre', in R. Cagnat (ed.), Mélanges Cagnat (Paris, 1912), 69; J. Carcopino, Cicero. The Secrets of His Correspondence, tr. E. O. Lorimer (New York, 1969), 11929; and Stockton (n. 2), 243-5, present a much more cynical interpretation of Cicero's boasting. 
years, and that Cicero investigated widespread corruption on the part of urban magistrates going back ten years (Att. 6.2.5). What is more, both Lentulus and Appius had played a role in Brutus' extortion of the Salaminians (Att. 5.21.11; 6.1.6).

Cicero's comments about his predecessors' rapacity, his desire to be a model governor, and the legal privileges that he bestowed on the province support the argument that the ban on evocatio originated with him. Unfortunately, in the absence of any further evidence from Cicero himself, the reasons why he would choose to exempt Cypriots from evocatio must remain uncertain. I would, however, suggest that there were three main reasons for his decision to issue such an exemption. First, we should consider Cicero's perpetual nurturing of his own reputation. He made no secret of his disgust at having to serve his year so far away from Rome (Att. 5.9.1, 5.11.1, 5.15.1, 5.18.1; Fam. 15.9.2, 15.12.2), and repeatedly begged Atticus to see to it that his tenure as governor was not extended (Att. 5.1.1, 5.9.2, $5.11 .5,5.13 .3)$. Yet he was determined to make that tenure a model one (Att. 5.18.2. 5.21.6, 6.1.2); in the words of Shackleton Bailey, 'Fame, not philanthropy or the beauty of virtue, was Cicero's spur.' ${ }^{\text {'5 }}$ However, it would be too cynical to dismiss any hint of altruism in Cicero's provincial governance, as he had long shown an interest in provincial affairs. ${ }^{16} \mathrm{~A}$ lengthy letter $(Q$ fr. 1.1$)$ from $c .60$ to his brother Quintus, at that time governor of Asia, is primarily concerned with how to be an exemplary magistrate. In this letter Cicero makes a number of recommendations, such as the need to resist monetary temptation (1.1.7), to make the happiness of the provincials a primary concern (1.1.24), to see to it that the best men among the provincials are administering justice in their own cities (1.1.25), and to both take care of and also restrain the tax-farmers (1.1.32). Each of these suggestions was reflected in his own conduct in Cilicia, conduct that

${ }^{15}$ D. R. Shackleton Bailey, Cicero (New York, 1972), 114. T. Mommsen, 'Der Zinswucher des M. Brutus', Hermes 34 (1899), 147, saw concern for his reputation as the reason for Cicero's favourable decision regarding Brutus' loan to Salamis. J. A. O. Larsen, 'Foreign Judges in Cicero Ad Atticum vi. 1. 15', CPh 43 (1948), 189, viewed Att. 6.1.15 as proof of Cicero's sympathy for the plight of the provincials; see also G. A. O. Hutchinson, Cicero's Correspondence (Oxford, 1998), 103-5.

${ }^{16}$ T. N. Mitchell, Cicero. The Senior Statesman (New Haven, CT, 1991), 204-18, provides an overview of Cicero's view of the duties of a provincial governor. E. S. Gruen, The Hellenistic World and the Coming of Rome (Berkeley, CA, 1984), 274-8, suggests that the contradictions found in Cicero's various writings indicate that he never gave much thought to the nature and quality of Roman imperialism; for an argument against Gruen, see P. Rose, 'Cicero and the Rhetoric of Imperialism: Putting the Politics Back into Political Rhetoric', Rhetorica 13 (1995) 360-79. 
would later draw praise from Plutarch (Vit. Cic. 36.1-2). We have seen that Cicero thought his predecessors, especially Appius, to be inferior to himself, and that he was quite proud of his provincial edict, which increased the autonomy of the cities in his province. His comments to Cato (Fam. 15.4.15) that all of Cyprus would sing his praises as governor may also indicate that he had acted beneficently towards all the cities, not only Salamis. It is thus not reaching too far to think that Cicero was the first governor to send a legate to Cyprus for legal reasons, or that he was the one to bestow the freedom from evocatio on the Cypriots.

Second, the strong Hellenistic influence on Cyprus and the previous Roman interaction with the island provided a cultural framework that encouraged a laissez-faire attitude. Though Cyprus had been under the domination of foreign powers for nearly four centuries, the cities of Cyprus were thoroughly Greek. They had developed along the model of the polis - that is, in the manner of a Greek city-state - and there is evidence that they were joined together in some sort of federation by at least the first century. Cyprus was so thoroughly Hellenized that Cicero felt comfortable referring to the Salaminians as Greeks (Att. 5.21.11). In contrast to the chronically disorganized province of Cilicia, Cyprus, by virtue of its Hellenistic traits and its pre-existing city structure, was much more likely to function satisfactorily on its own. ${ }^{17}$ In addition, Rome had maintained cordial relations with Cyprus since the late second century, primarily with regard to the pirate menace in the eastern Mediterranean, which was to some extent headquartered in Cilicia. To that end, the Ptolemaic king ruling in Cyprus had possessed philia kai summachia ('friendship and alliance') with the Romans as early as $102 .{ }^{18}$ In 56 Cicero would call the

\footnotetext{
${ }^{17}$ The sources for the Ptolemaic city constitutions have been collected in A. H. M. Jones, The Cities of the Eastern Roman Provinces (Oxford, 1937), 365-75; and Hill (n. 2), 179 n. 1. On the ton koinon tōn Kupriōn, the league of Cypriot cities, see Jones (this note), 373; Hill (n. 2), 185; and H. D. Purcell, Cyprus (New York, 1969), 95. On the cities' domination of Cyprus and their Hellenistic influences, see T. B. Mitford, 'The Character of Ptolemaic Rule in Cyprus', Aegyptus 33 (1953), 86; Marshall (n. 10), 210, n. 20; and Bernhardt (n. 3), 224. Cyprus' suitability for self-rule has been shown by Jones (this note), 365-75; see also Magie (n. 13), 385. On the convoluted history of Cilicia, see R. Syme, 'Observations on the Province of Cilicia', in W. M. Calder and J. Keil (eds.), Anatolian Studies Presented to William Hepburn Buckler (Manchester, 1939), 299-332; and T. B. Mitford, 'Roman Rough Cilicia', ANRW ii.7.2 (1980), 1230-61.

${ }^{18}$ For text and commentary on this law, see M. Hassall, M. Crawford, and J. Reynolds, 'Rome and the Eastern Provinces at the End of the Second Century B.c.', FRS 64 (1974), 195-220; and M. H. Crawford, Roman Statutes (London, 1996), 231-70. On the definitions of and distinctions between socius and amicus, see the seminal article by L. E. Matthaei, 'On the Classification of Roman Allies', CQ 1 (1907), 185-96.
} 
Cypriot Ptolemy semper amicus, semper socius, 'at all times a friend and ally' (Sest. 58). Cicero may have been exaggerating Ptolemy's status to inflate his attacks on Clodius, and being a socius et amicus did not mean that there was a formal treaty, or foedus, between Cyprus and Rome. Nevertheless, the nature of Cato's annexation did not reflect these traditional ties between Rome and the island. Cicero thought that the manner by which Cyprus passed under Roman suzerainty was highly irregular if not actually illegal (Dom. 20; Sest. 57, 59). He felt pity for the Salaminians against the depredations of Brutus and his collaborators (Att. 5.21.12, 6.1.6), and he maintained an affection for the Cypriots for many years, as his warm letter of recommendation to Sextilius Rufus demonstrates (Fam. 13.48).

A third consideration behind Cicero's decision to release the Cypriots from evocatio is the geography of the province of Cilicia. A great part of a governor's duties involved adjudication, or at least such was expected (Cic. $Q$ fr. 1.1.7). As long as he was based on the mainland, the governor could never exercise the sort of control over the cities of Cyprus as had the Ptolemaic king. By this fact alone the cities would have been forced to a great extent to operate independently. The bestowal to the Cypriots of some freedom from judicial summons had the benefit of eliminating the need for a potentially hazardous trip to Cyprus by the governor during the winter months. ${ }^{19}$ Protecting the islanders from undertaking the same dangerous journey surely would have garnered further favour with them. Moreover, by allowing much greater freedom to Cyprus Cicero would have avoided being caught on the island if the Parthians chose to invade. The Parthians worried him considerably, and most of his correspondence from his time in Cilicia describes his fears about them (Att. 5.20.2, 5.21.2, 6.1.14; Fam. 15.1-3, 2.10.2-4) and his reaction to their invasion of Syria (Att. 5.18.1, 6.4.1; Fam. 8.10.1-2). Finally, Cicero was in the habit of staying put for long periods. He did manage to see much of his province, and held assizes at several of the most important cities, including Laodicea, Apamea, Synnada, and Philomelium. ${ }^{20}$ But he also mentions holding assizes for many different areas in one place (Att. 5.21.9). In the event he spent over one-third of his tenure as governor

\footnotetext{
${ }^{19}$ Mitchell (n. 16), 225, comments that Volusius was sent only because Cicero himself had no opportunity to visit Cyprus; see also Marshall (n. 3), 238, on the placement of conventus according to the convenience of the governor.

${ }^{20}$ For a detailed timeline of Cicero's travel within his province, see L. W. Hunter, 'Cicero's Journey to his Province of Cilicia in 51 B.c.', $\mathcal{F} R S 3$ (1913), 73-97; and Marshall (n. 3), 242-5.
} 
in Laodicea, in the extreme west of Cilicia - on one occasion nearly four consecutive months holding an assize in early 50 (Att. 6.2.4).

In summary, Cicero's provincial edict is the most likely source of the ban on the evocatio of Cypriots. Cyprus never received a lex provinciae, and thus the prohibition must have been part of the provincial edict of one of the first three governors of the united province of CiliciaCyprus. Both of Cicero's predecessors in Cilicia were more concerned with personal enrichment than the wellbeing of the provincials, and are unlikely sources for the ban. Cicero's own desire to be a model governor, his deep concern for his reputation in Rome, and the convenience of leaving Cyprus to its own legal devices suggest that it was because of Cicero, not Cato, Lentulus, or Appius, that the Cypriots were exempted from this responsibility.

JONATHAN ZARECKI

jpzareck@uncg.edu 
Reproduced with permission of the copyright owner. Further reproduction prohibited without permission. 